\title{
Fortification of Cake with Sweet Potato and Beetroot Flour as Natural Antioxidant During Storage
}

\author{
Rasha M. Nagib ${ }^{1}$ and Nahla S. Zidan ${ }^{2}$
}

\begin{abstract}
The present work was conducted to assessed the quality of cake fortified with sweet potato and beet root flour. Sweet potato and beetroot composite were added at various levels of substitution $(5,10,15 \%)$ with wheat flour, cake production were carried out and these formula were storage for $0,7,14$ and 21 days. The proximate composition showed that there were an increased nutrient content (protein, ash, fiber, Phenol and flavonoids) as addition of wheat flour with sweet potato and beet root. Minerals content were determined ( $\mathrm{Ca}, \mathrm{Mg}, \mathrm{K}$ and $\mathrm{Fe}$ ). Adding sweet potato and beetroot increase levels of minerals comparing with control and during storage period. Sensory attributes of the cakes were examined results of analysis showed that decrease in sensory properties comparing with control cake and by increase period of storage. Rheological properties of dough were estimated. Antioxidant prosperities also determined. Sweet potato and beet root are good source of phenolic acids and flavonoids compound, considered as a functional food for due to health and nutritional values.
\end{abstract}

Keywords: Sweet potato, Beet root, Antioxidant, Chemical composition.

\section{INTRODUCTION}

Sweet potato (Ipomea batatas L.) is very important vegetable crop food in many countries including Egypt. It is a member of the family Convolvulaceae, in which there are over 400 Ipomea species distributed throughout the tropics, but sweet potato is the only one of economic importance. Beta-carotene-rich sweet potato is one of a few new crops, which is both an excellent source of energy and important nutritive substances that can contribute to improve the nutrient status of the community (Burri, 2011).

Sweet potato flour can serve as a source of energy and nutrients (carbohydrate, $\beta$-carotene, pro vitamin A), minerals $(\mathrm{Ca}, \mathrm{P}, \mathrm{Fe}, \mathrm{K}$, and $\mathrm{Z}$ ) and can add natural sweetness, color, flavor and dietary fiber to processed food products. It is also important to ensure that sweet potato-wheat based products have appropriates characteristics of appearance, aroma, taste and texture, which are key determinants of consumers' sensory acceptability of bakery products. Other sensory tests of cake products have found that replacing some basic components changes structure and volume of the crumb (Singh et al., 2008).

Beetroot (Beta vulgaris) is an excellent source of calcium, iron, fiber, and folic acid, beetroot are rich in valuable, active compounds such as carotenoids ,glycine, betaine, saponins, betacyanines, and folates , betanin, polyphenols and flavonoids (Jastrebova et al., 2003; Vali et al., 2007 and Dias et al., 2009). The beetroot species Beta vulgaris L. is considered a good source of minerals (potassium, sodium, iron, copper, magnesium, calcium, phosphorus and zinc), vitamins (retinol, ascorbic acid and B-complex), antioxidants, betalains and phenolic compounds and possesses high nutritional value due to its high glucose content, in the form of sucrose ( Lundberg et al ., 2008 and van Velzen et al ., 2008).

Cakes are convenient food products which are sweet and, usually prepared from wheat flour, sugar, shortening, baking powder and eggs as principal ingredients (Atef et al., 2011). The wheat which is the major ingredient, a cereal, is cultivated in many parts of the world, but imported by countries with unfavorable climatic conditions. There is a compelling need to develop an adequate substitute for wheat, as the demand and price of this product could further be increased by the unstable exchange rates. Cakes are usually made from soft wheat flour $72 \%$ extraction which low in fibers and phytochemicals. Recently, substitution fibers from various sources are obtainable as natural components, like fruit, and vegetable (Hafez, 2012 and Rodríguez et al., 2006).

The aim of the present study was to produce enriched cake with sweet potato and beet root as natural sources of antioxidants, that may help in prolonging the shelf life of the cake .

\section{MATERIALS AND METHODS}

\section{Materials:}

Sweet potato and beetroot flour were obtained from Egyptian baking technol. center. Wheat flour (72\%) was obtained from Milling Company, Dakahlia, Egypt. The eggs, sugar, vanilla and baking powder were purchased from local market in Dakahlia, Egypt. 


\section{Methods:}

\section{Preparation of cakes blends:}

The eggs, sugar and vanilla were mixed and creamed mechanically using electric mill for $10 \mathrm{~min}$ until soft and fluffy. The flour and baking powder were then added and mixed slightly until soft dough was formed. Sweet potato and beet root were substituted with wheat flour at different levels namely, 5, 10,15\%. The dough were transferred to a greased baking pan and baked in an oven at $180 \mathrm{C}^{\circ}$ for $35 \mathrm{~min}$. After cooling for $30 \mathrm{~min}$, the cakes were packed and used for evaluation of various chemical, physical and sensory characteristics A.A.C.C (1983).

\section{Gross chemical composition:}

Moisture, ash, crude protein and fat content were determined according to the method of A.O.A.C. (2000). Crude fiber was determined according to the method explained by Kirk and Sawer, (1991). Carbohydrates were calculated by difference $=100-(\%$ moisture $+\%$ protein $+\%$ fat $+\%$ ash $)$.

\section{Minerals:}

Mineral contents of all produced products $(\mathrm{Ca}, \mathrm{Mg}$, $\mathrm{K}$, and $\mathrm{Fe}$ ) were determined by A.O.A.C.(2000).

\section{Determination of total phenolic content:}

Total phenolic contents were determined in sweet potato and beet root flour by the Folin-Ciocalteu's method Meda et al., (2005).

\section{Determination of total flavonoids compounds:}

Total flavonoid (TF) content was determined based on the method described by Canadanovic-Brunet, et al., (2011).

\section{Determination of vitamin $\mathbf{C}$ content:}

The method described by Ohizua et al., (2017) was used to determine the vitamin $\mathrm{C}$ content of the cake samples.

\section{$\beta$ - Carotene content:}

The method described by Bhat and Bhat, (2013). The $\beta$-carotene was calculated using the following formula:

$\beta$-carotene $(\mathrm{mg} / 100 \mathrm{~g})=$ Optical density of sample $\times 13.9 \times 104 \times 100$ Weight of sample $\times 560 \times 1000$.

\section{Chemical properties of lipids during cake storage:}

Products of cakes were stored at room temperature for 21 days. The samples were kept in polyethylene bags until analyzed, they were analyzed every 7 days. Acid value and peroxide value of cake were determined according to the method of A.O.A.C. (2000). Thiobarbituric Acid (TBA) was determined according to the methods of Tarladgis et al., (1960).

\section{Sensory Evaluation:}

Cakes samples were subjected to sensory evaluation within 24 hours after production. The following attributes namely, taste, aroma, texture, appearance and overall acceptability were assessed on cake samples using a 7-point hedonic scale with 7 as like extremely and 1 as dislike extremely Ihekoronye and Ngoddy, (1985). Twenty panelists familiar with cake, who were neither sick nor allergic to baked products were involved in the assessment. The panelists were instructed to rinse their mouth with water after tasting each cake samples.

\section{Rheological properties:}

The rheological properties of wheat flours (72\% extraction) was determined using farinograph and extensograph according to the methods described in A.A.C.C. (1984).

\section{Statistical Analysis:}

All the obtained data were statistically analyzed by SPSS computer software. The calculated occurred by analysis of variance ANOVA and follow up test LSD by SPSS ver.11 according to Abo-Allam (2003).

\section{RERSULTS AND DISCUSSION}

The proximate chemical composition of sweet potato cake are presented in Table (1). As shown moisture, protein, fat, ash, carbohydrates, crud fiber, T. Phenol and flavonoids are included. Results indicated that moisture content decreased by increasing the period of storage in control cake and decreased by increasing level of sweet potato additive. Protein content increased by adding of sweet potato compared with control cake, it was $11.72,12.13,12.49$ and 12.78 in control cake and 5,10 and $15 \%$ sweet potato cake respectively. Storage led to protein deficiency in sweet potato cake by increasing storage period. The highest decrease noticed after 21 days storage. Total fat content increase by adding sweet potato comparing with control cake and increase during storage period. It ranged from 4.18 to 4.76 in control cake, 4.61 to 4.98 in $5 \%$ sweet potato cake, 4.27 to 4.83 in $10 \%$ sweet potato cake and 4.03 to 4.62 in $15 \%$ sweet potato cake. Ash content decreased by adding sweet potato comparing with control cake but increase by increase storage period .Total carbohydrates content increased in sweet potato cake comparing with control cake ,it ranged from 47.50 to 49.18 in control cake, 48.46 to 52.44 in $5 \%$ sweet potato cake, 50.24 to 54.1 in $10 \%$ sweet potato cake and 51.73 to 53.64 in $15 \%$ sweet potato cake respectively. 
Table 1. Effect of adding different levels of sweet potato flour on proximate chemical composition of prepared cake stored at room temperatures for 21 days (on dry weight basis)

\begin{tabular}{|c|c|c|c|c|c|c|c|c|c|}
\hline & & Moisture & C. protein & T. Fat & Ash & $\begin{array}{c}\text { Total } \\
\text { carbohydrates }\end{array}$ & C. fiber & $\begin{array}{c}\begin{array}{c}\text { T. Phenol } \\
\text { mg/g }\end{array} \\
\end{array}$ & $\begin{array}{c}\text { Flavonoid } \\
\mathrm{mg} / \mathrm{g}\end{array}$ \\
\hline \multirow{4}{*}{$\begin{array}{l}\overline{0} \\
\text { 苛 }\end{array}$} & 0 & $33.16 \pm 1.16^{\mathrm{a}}$ & $11.72 \pm 0.56^{\mathrm{b}}$ & $4.18 \pm 0.21^{b}$ & $3.44 \pm 0.0^{\mathrm{a}}$ & $47.5 \pm 1.9^{\mathrm{e}}$ & $8.97 \pm 0.31^{\mathrm{e}}$ & $1.98 \pm 0.06^{\mathrm{b}}$ & $1.09 \pm 0.05^{\mathrm{d}}$ \\
\hline & 7 & $32.51 \pm 0.81^{\mathrm{b}}$ & $11.47 \pm 0.25^{\mathrm{b}}$ & $4.39 \pm 0.24^{\mathrm{b}}$ & $3.58 \pm 0.11^{\mathrm{a}}$ & $48.05 \pm 1.87^{\mathrm{e}}$ & $9.32 \pm 0.23^{\mathrm{e}}$ & $2.30 \pm 0.07^{\mathrm{a}}$ & $1.28 \pm 0.07^{\mathrm{d}}$ \\
\hline & 14 & $31.8 \pm 1.27^{\mathrm{c}}$ & $11.28 \pm 0.34^{\mathrm{c}}$ & $4.58 \pm 0.16^{\mathrm{a}}$ & $3.76 \pm 0.19^{\mathrm{a}}$ & $48.58 \pm 2.19^{\mathrm{e}}$ & $9.51 \pm 0.38^{\mathrm{e}}$ & $2.49 \pm 0.15^{\mathrm{a}}$ & $1.52 \pm 0.05^{\mathrm{c}}$ \\
\hline & 21 & $31.41 \pm 1.1^{\mathrm{c}}$ & $11.02 \pm 0.55^{\mathrm{c}}$ & $4.76 \pm 0.14^{\mathrm{a}}$ & $3.90 \pm 0.21^{\mathrm{a}}$ & $49.18 \pm 2.16^{\mathrm{d}}$ & $10.05 \pm 0.66^{\mathrm{d}}$ & $2.61 \pm 0.16^{\mathrm{a}}$ & $1.69 \pm 0.05^{\mathrm{b}}$ \\
\hline \multirow{4}{*}{ 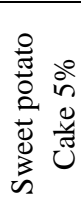 } & 0 & $32.05 \pm 1.25^{\mathrm{b}}$ & $12.13 \pm 0.67^{\mathrm{a}}$ & $4.61 \pm 0.2^{\mathrm{a}}$ & $2.75 \pm 0.18^{\mathrm{d}}$ & $48.46 \pm 2.13^{\mathrm{e}}$ & $10.35 \pm 0.51^{\mathrm{d}}$ & $1.44 \pm 0.06^{\mathrm{c}}$ & $0.89 \pm 0.04^{\mathrm{e}}$ \\
\hline & 7 & $30.91 \pm 1.24^{\mathrm{d}}$ & $11.87 \pm 0.77^{\mathrm{b}}$ & $4.75 \pm 0.31^{\mathrm{a}}$ & $2.97 \pm 0.21^{\mathrm{d}}$ & $49.5 \pm 2.82^{\mathrm{d}}$ & $11.07 \pm 0.72^{\mathrm{c}}$ & $1.68 \pm 0.07^{\mathrm{b}}$ & $0.99 \pm 0.07 \mathrm{e}$ \\
\hline & 14 & $29.87 \pm 1.34^{\mathrm{d}}$ & $11.43 \pm 0.8^{\mathrm{b}}$ & $4.86 \pm 0.27^{\mathrm{a}}$ & $3.19 \pm 0.1^{\mathrm{b}}$ & $50.65 \pm 2.38^{c}$ & $11.91 \pm 0.54^{\mathrm{c}}$ & $1.83 \pm 0.09^{\mathrm{b}}$ & $1.14 \pm 0.06^{\mathrm{d}}$ \\
\hline & 21 & $28.1 \pm 0.9^{\mathrm{e}}$ & $11.02 \pm 0.33^{\mathrm{c}}$ & $4.98 \pm 0.24^{\mathrm{a}}$ & $3.38 \pm 0.13^{b}$ & $52.44 \pm 2.36^{\mathrm{b}}$ & $12.89 \pm 0.97^{b}$ & $2.03 \pm 0.11^{\mathrm{a}}$ & $1.29 \pm 0.06^{\mathrm{d}}$ \\
\hline \multirow{4}{*}{ 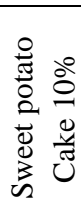 } & 0 & $29.96 \pm 1.44^{\mathrm{d}}$ & $=0.6^{\mathrm{a}}$ & $4.27 \pm 0.09^{\mathrm{b}}$ & 3. & $50.24 \pm 2.26^{\mathrm{c}}$ & $11.67 \pm 0.95^{\mathrm{c}}$ & $1.70 \pm 0.07^{\mathrm{b}}$ & $1.05 \pm 0.02^{\mathrm{d}}$ \\
\hline & 7 & $28.96 \pm 1.48^{\mathrm{d}}$ & $12.15 \pm 0.27^{\mathrm{a}}$ & $4.46 \pm 0.13^{b}$ & $3.19 \pm 0.18^{\mathrm{b}}$ & $51.38 \pm 2.83^{b}$ & $12.19 \pm 0.9^{\mathrm{b}}$ & $1.86 \pm 0.1^{\mathrm{b}}$ & $1.17 \pm 0.04^{\mathrm{d}}$ \\
\hline & 14 & $27.15 \pm 0.98^{d}$ & $11.73 \pm 0.35^{\mathrm{b}}$ & $4.69 \pm 0.23^{\mathrm{a}}$ & $3.36 \pm 0.1^{\mathrm{b}}$ & $53.07 \pm 2.12^{\mathrm{a}}$ & $13.09 \pm 0.58^{\mathrm{a}}$ & $2.06 \pm 0.14^{\mathrm{a}}$ & $1.41 \pm 0.07^{c}$ \\
\hline & 21 & $26.09 \pm 1.07^{\mathrm{e}}$ & $11.41 \pm 0.57^{\mathrm{b}}$ & $4.83 \pm 0.27^{\mathrm{a}}$ & $3.57 \pm 0.21^{\mathrm{a}}$ & $54.1 \pm 2.76^{\mathrm{a}}$ & $13.98 \pm 0.39^{\mathrm{a}}$ & $2.19 \pm 0.09^{\mathrm{a}}$ & $1.58 \pm 0.09^{c}$ \\
\hline \multirow{4}{*}{ 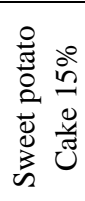 } & 0 & $28.2 \pm 1.24^{\mathrm{d}}$ & $12.78 \pm 0.7^{\mathrm{a}}$ & $4.03 \pm 0.26^{\mathrm{c}}$ & $3.26 \pm 0.16^{\mathrm{b}}$ & $51.73 \pm 2.53^{b}$ & $12.32 \pm 0.48^{b}$ & $1.89 \pm 0.06^{\mathrm{b}}$ & $1.27 \pm 0.06^{\mathrm{d}}$ \\
\hline & 7 & $27.61 \pm 1.35^{\mathrm{d}}$ & $12.59 \pm 0.82^{\mathrm{a}}$ & $4.20 \pm 0.29^{b}$ & $3.49 \pm 0.21^{\mathrm{a}}$ & $52.11 \pm 2.55^{\mathrm{b}}$ & $12.79 \pm 0.61^{b}$ & $2.1 \pm 0.1^{\mathrm{a}}$ & $1.45 \pm 0.09^{c}$ \\
\hline & 14 & $26.13 \pm 1.38^{\mathrm{e}}$ & $12.36 \pm 0.87^{\mathrm{a}}$ & $4.41 \pm 0.13^{b}$ & $3.68 \pm 0.26^{\mathrm{a}}$ & $53.42 \pm 2.72^{\mathrm{a}}$ & $13.27 \pm 0.37^{\mathrm{a}}$ & $2.35 \pm 0.13^{\mathrm{a}}$ & $1.69 \pm 0.05^{b}$ \\
\hline & 21 & $25.75 \pm 1.13^{\mathrm{e}}$ & $12.16 \pm 0.36^{a}$ & $4.62 \pm 0.22^{\mathrm{a}}$ & $3.83 \pm 0.15^{\mathrm{a}}$ & $53.64 \pm 2.36^{\mathrm{a}}$ & $13.89 \pm 0.32^{\mathrm{a}}$ & $2.61 \pm 0.11^{\mathrm{a}}$ & $1.92 \pm 0.09^{\mathrm{a}}$ \\
\hline
\end{tabular}

All results are expressed as mean $\pm \mathrm{SD}$

Values with the same letters indicate insignificant difference and vice versa.

Crude fiber content increased in sweet potato cake comparing with control cake it ranged from 8.97,10.35,11.67 and 12.32 in control cake and 5,10 and $15 \%$ sweet potato cake respectively. results showed that crude fiber content increased with storage period. Total phenol and flavonoids content decrease in sweet potato cake but increase with storage compared with control cake and the highest increase was in period of 21 days of storage .These data are similar to the study of Abd El-Wahab, (2016 ) and Alshehry, (2019) who showed that the sweet potato flour had the highest content of protein $12.71 \%$ and the blends were increased gradually by increasing sweet potato flour. Crude fiber higher in sweet potato flour 12. 62 than ash content and lipids 7.01 and $5.04 \%$, respectively. The sweet potato flour had contained total phenolic and flavonoids compounds.

The proximate chemical composition of beetroot cake are presented in Table (2). It can be noticed that moisture content in control cake was high compared to other fortified cake with beetroot. It's clear that moisture content was decreased by increasing the percentage of addition and the storage period increased. From table (1) it could be noticed that protein content increased by increase the percentage of beet root, the highest content noticed in $15 \%$ beetroot cake but decrease during storage period. Total fat content ranged from 4.18 to
4.76 control cake. Fat content decrease with increase percentage of beet root. From results fat content increase with increase period of storage from zero time to 21 days. Ash content ranged from 3.54 to 3.90 in control cake, it noticed ash content increase with storage period it ranged from 3.60 to 4.04 in $5 \%$ beetroot cake and 3.77 to 4.25 in $10 \%$ beetroot cake and 3.97 to 4.41 in $15 \%$ beetroot cake. Total carbohydrates ranged from 47.50 to 49.18 in control cake. From results total carbohydrates increase by increase the content of beetroot powder and it ranged from 48.44 to 50.38 in $5 \%$ beetroot cake and 48.94 to 50.90 in $10 \%$ beetroot cake and 49.46 to 51.18 in $15 \%$ beetroot cake. Crude fiber content increase by adding beet root and increase period of storage from zero time to 21 days. Total phenol and total flavonoids were increased by adding beet root percentage and during storage period it ranged from 1.98 to $2.61 \mathrm{mg} / \mathrm{g}$ in control cake 2.29 to 3.09 $\mathrm{mg} / \mathrm{g}$ in $5 \%$ beetroot cake ,2.71 to $3.38 \mathrm{mg} / \mathrm{g}$ in $10 \%$ beetroot cake and 2.98 to $3.92 \mathrm{mg} / \mathrm{g}$ in $15 \%$ beetroot cake in total phenol. Total flavonoids content ranged from 1.09 to 1.69 in control cake ,1.32 to 1.98 in 5\% beetroot cake, 1.47 to 2.25 in $10 \%$ beetroot cake and 1.72 to 2.60 in $15 \%$ beetroot cake. The same results were agreed by Nazni and Karuna Thara, (2011). 
Table 2. Effect of adding different levels of beetroot flour on proximate chemical composition of prepared cake stored at room temperatures for 21 days (on dry weight basis)

\begin{tabular}{|c|c|c|c|c|c|c|c|c|c|}
\hline & & Moistu & C. protein & Fat & Ash & $\begin{array}{c}\text { Total } \\
\text { carbohydrates }\end{array}$ & 0 & $\begin{array}{c}\text { T. Phenol } \\
\text { mg/g }\end{array}$ & $\begin{array}{l}\text { Flavonoid } \\
\mathrm{mg} / \mathrm{g}\end{array}$ \\
\hline \multirow{4}{*}{ 高 } & 0 & & & & & $7.5 \pm 2$ & & 1.98 & \\
\hline & 7 & & & & & & & & \\
\hline & 14 & & & & & & & & \\
\hline & 21 & & & & & 40 & & & \\
\hline \multirow{4}{*}{ 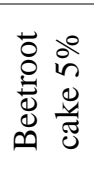 } & 8 & & & & & & & & \\
\hline & 7 & & & 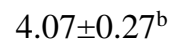 & & 49. & & & \\
\hline & 14 & 30.5 & & 4.26 & 3.93 & 49.7 & . & 2.88 & \\
\hline & 21 & & & 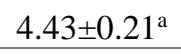 & 4.0 & & & 3.09 & \\
\hline \multirow{4}{*}{ 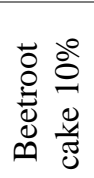 } & 0 & & & & & & & 2.71 & \\
\hline & 7 & & & & 3.9 & & & 2.98 & \\
\hline & 14 & & & & & & & & \\
\hline & 21 & & & & 4.25 & $50.9 \pm 3.05^{\mathrm{a}}$ & & 3.3 & \\
\hline \multirow{4}{*}{ 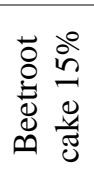 } & 0 & & & & & & & & \\
\hline & 7 & & & & & 50.2 & & $3.21 \pm$ & $1.99 \pm 0.13$ \\
\hline & 14 & & & & 4.25 & & & $3.53 \pm$ & $2.39 \pm 0.17$ \\
\hline & 21 & $29.16 \pm 0.73^{e}$ & $11.61 \pm 0.56^{\mathrm{b}}$ & $3.87 \pm 0.19^{c}$ & $4.41 \pm 0.3^{\mathrm{a}}$ & $51.18 \pm 2.00^{\mathrm{a}}$ & $11.19 \pm 0.26^{\mathrm{a}}$ & $3.92 \pm 0.15^{\mathrm{a}}$ & $2.6 \pm 0.08^{\mathrm{a}}$ \\
\hline
\end{tabular}

All results are expressed as mean $\pm \mathrm{SD}$

Values with the same letters indicate insignificant difference and vice versa.

Table 3. Effect of adding sweet potato on Thiobarbituric acid (TBA), the acid value (AV), peroxide value (PV), Beta Carotene and Vitamin $C$ in cakes stored at room temperatures for 21 days

\begin{tabular}{|c|c|c|c|c|c|c|}
\hline Storag & riod & T.P.A ppm & $\mathbf{A V}$ & PV meq/kg & $\begin{array}{c}\text { B.carotien } \\
\text { mg/100g }\end{array}$ & VC \\
\hline \multirow{4}{*}{ 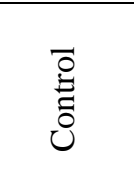 } & 0 & $0.140 \pm 0.003^{c}$ & $7.02 \pm 0.246^{\mathrm{a}}$ & $12.49 \pm 0.4^{\mathrm{b}}$ & $0.71 \pm 0.036^{\mathrm{e}}$ & $1.84 \pm 0.05^{\mathrm{f}}$ \\
\hline & 7 & $0.169 \pm 0.005^{b}$ & $6.96 \pm 0.174^{\mathrm{a}}$ & $12.83 \pm 0.372^{a}$ & $0.52 \pm 0.029^{\mathrm{e}}$ & $1.13 \pm 0.04^{\mathrm{f}}$ \\
\hline & 14 & $0.197 \pm 0.01^{b}$ & $6.88 \pm 0.275^{\mathrm{a}}$ & $13.03 \pm 0.795^{\mathrm{a}}$ & $0.43 \pm 0.015^{\mathrm{e}}$ & $0.81 \pm 0.02^{f}$ \\
\hline & 21 & $0.223 \pm 0.012^{\mathrm{a}}$ & $6.82 \pm 0.239^{a}$ & $13.3 \pm 0.798^{a}$ & $0.36 \pm 0.010^{\mathrm{e}}$ & $0.59 \pm 0.02^{\mathrm{f}}$ \\
\hline \multirow{4}{*}{ 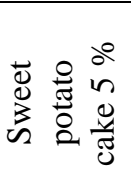 } & 0 & $0.104 \pm 0.007^{\mathrm{d}}$ & $7.12 \pm 0.278^{a}$ & $12.33 \pm 0.543^{c}$ & $3.09 \pm 0.136^{b}$ & $17.87 \pm 0.73^{\mathrm{c}}$ \\
\hline & 7 & $0.147 \pm 0.01^{\mathrm{c}}$ & $7.03 \pm 0.281^{\mathrm{a}}$ & $12.76 \pm 0.48^{\mathrm{a}}$ & $2.68 \pm 0.177^{c}$ & $12.41 \pm 0.42^{\mathrm{d}}$ \\
\hline & 14 & $0.181 \pm 0.005^{b}$ & $6.95 \pm 0.313^{\mathrm{a}}$ & $13.02 \pm 0.612^{\mathrm{a}}$ & $1.93 \pm 0.106^{\mathrm{d}}$ & $8.54 \pm 0.27^{\mathrm{e}}$ \\
\hline & 21 & $0.212 \pm 0.008^{a}$ & $6.81 \pm 0.218^{a}$ & $13.43 \pm 0.752^{a}$ & $1.52 \pm 0.073^{\mathrm{d}}$ & $6.43 \pm 0.29^{\mathrm{e}}$ \\
\hline \multirow{4}{*}{  } & 0 & $0.092 \pm 0.005^{\mathrm{d}}$ & $7.19 \pm 0.316^{\mathrm{a}}$ & $12.07 \pm 0.398^{\mathrm{c}}$ & $4.68 \pm 0.304^{b}$ & $21.05 \pm 0.46^{b}$ \\
\hline & 7 & $0.133 \pm 0.008^{c}$ & $7.1 \pm 0.348^{a}$ & $12.59 \pm 0.592^{b}$ & $3.42 \pm 0.239^{b}$ & $16.33 \pm 0.49^{\mathrm{c}}$ \\
\hline & 14 & $0.169 \pm 0.012^{b}$ & $7.06 \pm 0.374^{\mathrm{a}}$ & $12.86 \pm 0.707^{\mathrm{a}}$ & $2.08 \pm 0.062^{c}$ & $10.41 \pm 0.52^{\mathrm{d}}$ \\
\hline & 21 & $0.199 \pm 0.008^{b}$ & $6.95 \pm 0.306^{a}$ & $13.09 \pm 0.55^{\mathrm{a}}$ & $2.49 \pm 0.12^{c}$ & $8.21 \pm 0.45^{\mathrm{e}}$ \\
\hline \multirow{4}{*}{ 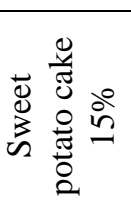 } & 0 & $0.083 \pm 0.004^{\mathrm{d}}$ & $7.23 \pm 0.282^{\mathrm{a}}$ & $11.81 \pm 0.52^{\mathrm{d}}$ & $6.93 \pm 0.485^{\mathrm{a}}$ & $27.16 \pm 1.22^{\mathrm{a}}$ \\
\hline & 7 & $0.127 \pm 0.007^{\mathrm{c}}$ & $7.18 \pm 0.287^{\mathrm{a}}$ & $12.07 \pm 0.797^{\mathrm{c}}$ & $5.94 \pm 0.178^{a}$ & $22.18 \pm 1.22^{b}$ \\
\hline & 14 & $0.158 \pm 0.007^{\mathrm{c}}$ & $7.09 \pm 0.319^{a}$ & $12.41 \pm 0.683^{b}$ & $5.18 \pm 0.202^{a}$ & $16.32 \pm 0.49^{\mathrm{c}}$ \\
\hline & 21 & $0.187 \pm 0.008^{b}$ & $7.02 \pm 0.225^{\mathrm{a}}$ & $12.68 \pm 0.609^{b}$ & $4.82 \pm 0.217^{b}$ & $11.39 \pm 0.68^{\mathrm{d}}$ \\
\hline
\end{tabular}

All results are expressed as mean \pm SD

Values with the same letters indicate insignificant difference and vice versa. 
Thiobarbituric acid (TBA), acid value (AV), peroxide value (PV), Beta Carotene and Vitamin C values of cake supplemented with sweet potato during storage are given in Table (3). Results showed that TBA value for control sample is higher than other samples that has been tested. In control cake TBA value increase during storage,TBA values decreased by adding sweet potato in all concentration 5,10 and $15 \%$. The highest decrease noticed in $15 \%$ sweet potato cake it was 0.083 ppm at zero time, but during storage period noticed also increase in TBA value. All samples resulted in lower TBA values when compared to the control, which indicates that the natural antioxidants in corporate into cakes exhibited antioxidant properties and preventing lipid oxidation in cakes. Acid value (AV) content showed not significantly different in all tested samples compared to the control. Peroxide value decreased by adding sweet potato in all concentration 5,10 and $15 \%$ while increase during storage period. Beta carotene and Vitamin $\mathrm{C}$ were increase by adding sweet potato in all concentration 5,10 and $15 \%$ but decrease during storage period. These results are agreed with (Hafez, 2012 and Okorie, and Onyeneke, 2012).

Thiobarbituric acid (TBA), acid value (AV), peroxide value (PV), Beta Carotene and Vitamin C values of cake supplemented with beetroot during storage are given in Table (4). Results showed that TBA value for control sample is higher than other samples that has been tested. In All samples TBA value increase during storage value but decreased by adding beetroot in all concentration 5,10 and $15 \%$. All samples resulted in lower TBA values when compared to the control. Acid value (AV) content showed not significantly different in all tested samples compared to the control. Peroxide value decreased by adding beetroot in all concentration 5,10 and $15 \%$ while increase during storage period. Beta carotene and Vitamin $\mathrm{C}$ were increase by adding beetroot in all concentration 5,10 and $15 \%$ but decrease during storage period. These results are agreed with (Frank et al ,2005; Manach et al ,2005 and Georgiev et al ,2010).

Table (5) shows the result of the minerals composition of the sweet potato and beetroot flour on minerals content of prepared cake stored at room temperatures for 21 days. From the resultant, it could be noticed that calcium content in the examined samples ranged from 178 to 241 in control cake , 47.2 to 56.1, 197 to 255 , in $5 \%$ sweet potato and beetroot cake, 54.7 to $60.90,218$ to 271 in $10 \%$ sweet potato and beetroot cake and 63.20 to $73.80,239$ to 295 in $15 \%$ sweet potato and beetroot cake. Magnesium functions as a cofactor of many enzymes involved in energy metabolism, protein synthesis, RNA and DNA synthesis,

Table 4. Effect of adding beetroot on Thiobarbituric acid (TBA), the acid value (AV), peroxide value (PV), Beta Carotene and Vitamin $C$ in cakes stored at room temperatures for 21 days

\begin{tabular}{|c|c|c|c|c|c|c|}
\hline \multicolumn{2}{|c|}{ Storage period } & T.P.A ppm & AV & PV meq/kg & $\begin{array}{c}\text { B.carotien } \\
\text { mg/100g }\end{array}$ & VC \\
\hline \multirow{4}{*}{$\begin{array}{l}\bar{O} \\
\stackrel{0}{0}\end{array}$} & 0 & $0.140 \pm 0.003^{c}$ & $7.02 \pm 0.246^{\mathrm{a}}$ & $12.49 \pm 0.4^{b}$ & $0.71 \pm 0.036^{\mathrm{e}}$ & $1.84 \pm 0.05^{\mathrm{c}}$ \\
\hline & 7 & $0.169 \pm 0.005^{b}$ & $6.96 \pm 0.174^{\mathrm{a}}$ & $12.83 \pm 0.372^{\mathrm{a}}$ & $0.52 \pm 0.029^{e}$ & $1.13 \pm 0.04^{\mathrm{c}}$ \\
\hline & 14 & $0.197 \pm 0.01^{b}$ & $6.88 \pm 0.275^{a}$ & $13.03 \pm 0.795^{\mathrm{a}}$ & $0.43 \pm 0.015^{\mathrm{e}}$ & $0.81 \pm 0.02^{\mathrm{d}}$ \\
\hline & 21 & $0.223 \pm 0.012^{a}$ & $6.82 \pm 0.239^{a}$ & $13.30 \pm 0.798^{\mathrm{a}}$ & $0.36 \pm 0.01^{\mathrm{e}}$ & $0.59 \pm 0.02^{\mathrm{e}}$ \\
\hline \multirow{4}{*}{ 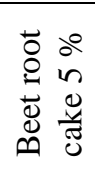 } & 0 & $0.119 \pm 0.005^{\mathrm{d}}$ & $7.09 \pm 0.34^{\mathrm{a}}$ & $12.16 \pm 0.523^{c}$ & $2.09 \pm 0.046^{\mathrm{c}}$ & $2.55 \pm 0.05^{b}$ \\
\hline & 7 & $0.142 \pm 0.008^{c}$ & $7.03 \pm 0.359^{\mathrm{a}}$ & $12.34 \pm 0.679^{c}$ & $1.87 \pm 0.056^{\mathrm{d}}$ & $2.12 \pm 0.06^{b}$ \\
\hline & 14 & $0.160 \pm 0.005^{b}$ & $6.97 \pm 0.251^{\mathrm{a}}$ & $12.63 \pm 0.846^{b}$ & $1.59 \pm 0.08^{\mathrm{d}}$ & $1.85 \pm 0.06^{\mathrm{c}}$ \\
\hline & 21 & $0.187 \pm 0.011^{b}$ & $6.91 \pm 0.283^{\mathrm{a}}$ & $12.79 \pm 0.55^{\mathrm{a}}$ & $1.35 \pm 0.074^{\mathrm{d}}$ & $1.49 \pm 0.04^{\mathrm{c}}$ \\
\hline \multirow{4}{*}{ 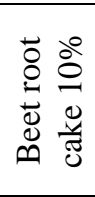 } & 0 & $0.108 \pm 0.004^{\mathrm{d}}$ & $7.16 \pm 0.251^{a}$ & $12.03 \pm 0.602^{\mathrm{c}}$ & $3.66 \pm 0.11^{\mathrm{b}}$ & $3.61 \pm 0.23^{\mathrm{a}}$ \\
\hline & 7 & $0.129 \pm 0.005^{\mathrm{d}}$ & $7.09 \pm 0.177^{\mathrm{a}}$ & $12.19 \pm 0.67^{\mathrm{c}}$ & $3.10 \pm 0.155^{b}$ & $3.43 \pm 0.24^{\mathrm{a}}$ \\
\hline & 14 & $0.147 \pm 0.007^{\mathrm{c}}$ & $7.03 \pm 0.281^{\mathrm{a}}$ & $12.40 \pm 0.434^{b}$ & $2.88 \pm 0.158^{c}$ & $3.17 \pm 0.1^{\mathrm{a}}$ \\
\hline & 21 & $0.168 \pm 0.007^{b}$ & $6.97 \pm 0.244^{\mathrm{a}}$ & $12.61 \pm 0.366^{b}$ & $2.61 \pm 0.17^{\mathrm{c}}$ & $2.95 \pm 0.12^{b}$ \\
\hline \multirow{4}{*}{ 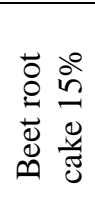 } & 0 & $0.098 \pm 0.004^{\mathrm{e}}$ & $7.09 \pm 0.34^{\mathrm{a}}$ & $11.81 \pm 0.26^{\mathrm{d}}$ & $4.15 \pm 0.228^{a}$ & $3.98 \pm 0.2^{\mathrm{a}}$ \\
\hline & 7 & $0.114 \pm 0.006^{d}$ & $7.14 \pm 0.364^{\mathrm{a}}$ & $12.03 \pm 0.361^{\mathrm{c}}$ & $3.92 \pm 0.118^{b}$ & $3.36 \pm 0.2^{\mathrm{a}}$ \\
\hline & 14 & $0.136 \pm 0.005^{c}$ & $7.08 \pm 0.255^{\mathrm{a}}$ & $12.20 \pm 0.61^{c}$ & $3.73 \pm 0.224^{b}$ & $3.09 \pm 0.15^{\mathrm{a}}$ \\
\hline & 21 & $0.159 \pm 0.008^{b}$ & $7.02 \pm 0.288^{a}$ & $12.38 \pm 0.681^{\mathrm{c}}$ & $3.40 \pm 0.167^{b}$ & $2.52 \pm 0.11^{\mathrm{b}}$ \\
\hline
\end{tabular}

All results are expressed as mean \pm SD

Values with the same letters indicate insignificant difference and vice versa. 
and maintenance of the electrical potential of nervous tissues and cell membranes. Of particular importance with respect to the pathological effects of magnesium depletion is the role of this element in regulating potassium fluxes and its involvement in the metabolism of calcium. Magnesium ranged from 23.6 to 27.5 in control cake, 31.60 to $37.5,28.9$ to 38.2 in $5 \%$ sweet potato and beetroot cake ,36.8 to $42.7,37.4$ to 50.30 in $10 \%$ sweet potato and beetroot cake and 43.4 to 51.50 43.5 to 50.1 in $15 \%$ sweet potato and beetroot cake. Potassium is an essential nutrient needed for maintenance of total body fluid volume, acid and electrolyte balance, and normal cell function. Potassium values ranged from 86 to 117 in control cake 604.3 to $689.1,112$ to 176 , in $5 \%$ sweet potato and beetroot ,665.1 to $787.3,177$ to 231 , in $10 \%$ sweet potato and beetroot cake and 809.2 to $927.4,193$ to 265 , in $15 \%$ sweet potato and beetroot cake. Iron has several vital functions in the body. It serves as a carrier of oxygen to the tissues from the lungs by red blood cell hemoglobin, as a transport medium for electrons within cells, and as an integrated part of important enzyme systems in various tissues. iron ranged from 13.9 to 16.3 in control cake, 0.88 to $1.29,15.2$ to 20.1 in $5 \%$ sweet potato and beetroot cake, 1.43 to $1.88,16.8$ to 21.5 in $10 \%$ sweet potato and beetroot cake and 2.03 to $2.61,18.7$ to 25.7 in $15 \%$ sweet potato and beetroot cake. Sweet potato flour can serve as a source of energy and nutrients (carbohydrate, $\beta$-carotene, provitamin A), minerals $(\mathrm{Ca}$, $\mathrm{P}, \mathrm{Fe}, \mathrm{K}$, and Z) (Singh et al., 2008 and Olatunde, et al., 2019).

Table 5. Effect of adding different levels of sweet potato and beetroot flour on minerals content of prepared cake stored at room temperatures for 21 days

\begin{tabular}{|c|c|c|c|c|c|}
\hline \multicolumn{6}{|c|}{ Minerals } \\
\hline Storage 1 & & $\mathbf{C a}$ & Mg & $\mathbf{K}$ & $\mathbf{F e}$ \\
\hline \multirow{4}{*}{ Control } & 0 & $178 \pm 3.92^{b}$ & $23.6 \pm 1.06^{\mathrm{e}}$ & $117 \pm 5.85^{\mathrm{d}}$ & $13.9 \pm 0.7^{b}$ \\
\hline & 7 & $193 \pm 5.79^{b}$ & $25.1 \pm 1.38^{\mathrm{d}}$ & $105 \pm 5.78^{d}$ & $14.5 \pm 0.87^{b}$ \\
\hline & 14 & $218 \pm 10.9^{\mathrm{a}}$ & $26.7 \pm 0.8^{\mathrm{d}}$ & $92 \pm 3.22 \mathrm{e}^{\mathrm{e}}$ & $15.4 \pm 0.69^{b}$ \\
\hline & 21 & $241 \pm 13.26^{\mathrm{a}}$ & $27.5 \pm 1.65^{\mathrm{d}}$ & $86 \pm 2.49^{\mathrm{e}}$ & $16.3 \pm 1.08^{b}$ \\
\hline \multirow{4}{*}{$\begin{array}{c}\text { Sweet } \\
\text { potato cake } \\
5 \%\end{array}$} & 0 & $47.2 \pm 3.07^{\mathrm{e}}$ & $31.6 \pm 1.55^{\mathrm{c}}$ & $604.3 \pm 26.59^{b}$ & $0.88 \pm 0.04^{\mathrm{e}}$ \\
\hline & 7 & $49.6 \pm 3.47^{\mathrm{e}}$ & $33 . \pm 20.01^{\mathrm{c}}$ & $623.7 \pm 41.16^{b}$ & $0.96 \pm 0.06^{\mathrm{e}}$ \\
\hline & 14 & $53.7 \pm 1.61^{\mathrm{e}}$ & $35.9 \pm 2.51^{\mathrm{c}}$ & $674.3 \pm 37.09^{b}$ & $1.13 \pm 0.05^{\mathrm{d}}$ \\
\hline & 21 & $56.1 \pm 2.19^{\mathrm{e}}$ & $37.5 \pm 1.46^{\mathrm{c}}$ & $689.1 \pm 33.08^{\mathrm{b}}$ & $1.29 \pm 0.07^{\mathrm{d}}$ \\
\hline \multirow{4}{*}{$\begin{array}{l}\text { Beetroot } \\
\text { cake } 5 \%\end{array}$} & 0 & $197 \pm 10.84^{b}$ & $28.9 \pm 1.45^{\mathrm{d}}$ & $176 \pm 3.87^{\mathrm{c}}$ & $15.2 \pm 0.53^{b}$ \\
\hline & 7 & $208 \pm 11.44^{\mathrm{a}}$ & $30.4 \pm 1.67^{\mathrm{c}}$ & $152 \pm 4.56^{\mathrm{c}}$ & $16.7 \pm 1.02^{b}$ \\
\hline & 14 & $223 \pm 14.72^{a}$ & $33.1 \pm 1.16^{\mathrm{c}}$ & $133 \pm 6.65^{\mathrm{d}}$ & $18.3 \pm 0.93^{\mathrm{a}}$ \\
\hline & 21 & $255 \pm 8.93^{\mathrm{a}}$ & $38.2 \pm 1.11^{\mathrm{c}}$ & $112 \pm 6.16^{\mathrm{d}}$ & $20.1 \pm 0.88^{\text {a }}$ \\
\hline \multirow{4}{*}{$\begin{array}{c}\text { Sweet } \\
\text { potato cake } \\
10 \%\end{array}$} & 0 & $54.7 \pm 2.41^{\mathrm{e}}$ & $36.8 \pm 1.62^{\mathrm{c}}$ & $665.1 \pm 43.23^{b}$ & $1.43 \pm 0.04^{\mathrm{d}}$ \\
\hline & 7 & $56 . \pm 3.98^{\mathrm{e}}$ & $38.1 \pm 2.51^{\mathrm{c}}$ & $716.4 \pm 50.15^{a}$ & $1.65 \pm 0.06^{\mathrm{d}}$ \\
\hline & 14 & $58.3 \pm 3.79^{\mathrm{e}}$ & $41.2 \pm 2.27^{\mathrm{b}}$ & $738.9 \pm 22.17^{\mathrm{a}}$ & $1.76 \pm 0.08^{\mathrm{d}}$ \\
\hline & 21 & $60.9 \pm 2.01^{\mathrm{d}}$ & $42.7 \pm 2.05^{\mathrm{b}}$ & $787.3 \pm 37.79^{\mathrm{a}}$ & $1.88 \pm 0.05^{\mathrm{d}}$ \\
\hline \multirow{4}{*}{$\begin{array}{c}\text { Beetroot } \\
\text { cake } 10 \%\end{array}$} & 0 & $218 \pm 10.46^{\mathrm{a}}$ & $37.4 \pm 1.8^{\mathrm{c}}$ & $231 \pm 5.08^{c}$ & $16.8 \pm 0.76^{b}$ \\
\hline & 7 & $243 \pm 12.39^{\mathrm{a}}$ & $40.6 \pm 0.89^{b}$ & $208 \pm 6.24^{\mathrm{c}}$ & $18.1 \pm 1^{\mathrm{a}}$ \\
\hline & 14 & $259 \pm 9.32^{\mathrm{a}}$ & $45.7 \pm 1.37^{\mathrm{b}}$ & $190 \pm 9.5^{c}$ & $19.8 \pm 0.59^{\mathrm{a}}$ \\
\hline & 21 & $271 \pm 11.11^{\mathrm{a}}$ & $50.3 \pm 2.52^{\mathrm{a}}$ & $177 \pm 9.74^{\mathrm{c}}$ & $21.5 \pm 1.29^{\mathrm{a}}$ \\
\hline \multirow{4}{*}{$\begin{array}{c}\text { Sweet } \\
\text { potato cake } \\
15 \%\end{array}$} & 0 & $63.2 \pm 2.78^{\mathrm{d}}$ & $43.4 \pm 2.39^{b}$ & $809.2 \pm 52.6^{\mathrm{a}}$ & $2.03 \pm 0.1^{\mathrm{c}}$ \\
\hline & 7 & $66.5 \pm 3.26^{\mathrm{d}}$ & $47.3 \pm 3.07^{\mathrm{b}}$ & $857.5 \pm 60.03^{\mathrm{a}}$ & $2.29 \pm 0.14^{\mathrm{c}}$ \\
\hline & 14 & $71.4 \pm 3.78^{c}$ & $50.6 \pm 3.54^{\mathrm{a}}$ & $903.7 \pm 27.11^{\mathrm{a}}$ & $2.48 \pm 0.17^{\mathrm{c}}$ \\
\hline & 21 & $73.8 \pm 3.25^{\mathrm{c}}$ & $51.5 \pm 1.55^{\mathrm{a}}$ & $927.4 \pm 44.52^{\mathrm{a}}$ & $2.61 \pm 0.1^{\mathrm{c}}$ \\
\hline \multirow{4}{*}{$\begin{array}{c}\text { Beetroot } \\
\text { cake } 15 \%\end{array}$} & 0 & $239 \pm 8.37^{\mathrm{a}}$ & $43.5 \pm 2.09^{b}$ & $265 \pm 13.25^{c}$ & $18.7 \pm 0.41^{\mathrm{a}}$ \\
\hline & 7 & $261 \pm 6.53^{\mathrm{a}}$ & $45.6 \pm 1.0^{\mathrm{b}}$ & $239 \pm 13.15^{\mathrm{c}}$ & $20.6 \pm 0.62^{\mathrm{a}}$ \\
\hline & 14 & $278 \pm 11.12^{\mathrm{a}}$ & $47.3 \pm 1.42^{b}$ & $201 \pm 7.04^{\mathrm{c}}$ & $22.4 \pm 1.12^{\mathrm{a}}$ \\
\hline & 21 & $295 \pm 10.33^{\mathrm{a}}$ & $50.1 \pm 2.51^{\mathrm{a}}$ & $193 \pm 5.6^{c}$ & $25.7 \pm 1.41^{\mathrm{a}}$ \\
\hline
\end{tabular}

All results are expressed as mean $\pm \mathrm{SD}$

Values with the same letters indicate insignificant difference and vice versa. 
Data in Table (6) showed the Effect of adding different levels of sweet potato and beetroot flour $(5,10$ and $15 \%$ ) on sensory evaluation of prepared cake stored at room temperatures for 21 days including taste, flavor, texture ,appearance and overall acceptability. Sensory evaluation is usually performed towards the end of the product development or formulation cycle and is carried out to assess the reaction of judges towards the product and they rate the liking on a scale. It could be noticed that cake treatments made from $100 \%$ wheat flour (extraction $72 \%$ ) was characterized with high acceptability for all parameters. There is no significant different were observed with regard to sensory evaluation (taste, flavor, texture, appearance and acceptability) of cake and its blends and it is still acceptable in previous parameters as compared to the control cake. Therefore, the sweet potato and beetroot flour has been considered as a potential source of vegetable protein, dietary fiber and natural antioxidant for human consumption. The blend flavor, color and absence of antinutritional factors or allergenic compounds have prompted the utilization of the cake for human consumption (Singh et al, 2008 and Awasthi, 2014).

Table 6. Effect of adding different levels of sweet potato and beetroot flour on sensory evaluation of prepared cake stored at room temperatures for 21 days

\begin{tabular}{|c|c|c|c|c|c|c|}
\hline \multicolumn{2}{|c|}{ Storage period } & \multirow{2}{*}{$\frac{\text { Taste }}{9.00 \pm 0.38^{a}}$} & \multirow{2}{*}{$\begin{array}{c}\text { Flavor } \\
9.0 \pm 0.32^{\mathrm{a}}\end{array}$} & \multirow{2}{*}{$\begin{array}{c}\text { Texture } \\
8.7 \pm 0.17^{\mathrm{a}}\end{array}$} & \multirow{2}{*}{$\begin{array}{c}\text { Appearance } \\
8.7 \pm 0.27^{\mathrm{a}}\end{array}$} & \multirow{2}{*}{$\frac{\text { Acceptability }^{\mathrm{a}}}{8.1 \pm 0.21^{\mathrm{a}}}$} \\
\hline \multirow{4}{*}{ Control } & 0 & & & & & \\
\hline & 7 & $8.30 \pm 0.18^{b}$ & $9.0 \pm 0.28^{\mathrm{a}}$ & $7.9 \pm 0.25^{b}$ & $7.8 \pm 0.14^{b}$ & $7.4 \pm 0.27^{\mathrm{b}}$ \\
\hline & 14 & $7.90 \pm 0.25^{b}$ & $8.9 \pm 0.28^{a}$ & $7.6 \pm 0.11^{b}$ & $7.1 \pm 0.22^{b}$ & $7.3 \pm 0.27^{b}$ \\
\hline & 21 & $7.40 \pm 0.25^{\mathrm{c}}$ & $8.6 \pm 0.12^{b}$ & $6.0 \pm 0.12^{\mathrm{c}}$ & $7.0 \pm 0.26^{\mathrm{b}}$ & $6.4 \pm 0.29^{c}$ \\
\hline \multirow{4}{*}{$\begin{array}{c}\text { Sweet } \\
\text { potato cake } \\
5 \%\end{array}$} & 0 & $7.50 \pm 0.18^{c}$ & $8.4 \pm 0.17^{b}$ & $7.3 \pm 0.24^{b}$ & $7.3 \pm 0.15^{b}$ & $6.8 \pm 0.16^{c}$ \\
\hline & 7 & $7.30 \pm 0.2^{c}$ & $6.8 \pm 0.23^{\mathrm{d}}$ & $7.0 \pm 0.26^{\mathrm{b}}$ & $7.2 \pm 0.29^{b}$ & $4.3 \pm 0.14^{\mathrm{d}}$ \\
\hline & 14 & $4.40 \pm 0.14^{\mathrm{e}}$ & $3.9 \pm 0.17^{\mathrm{e}}$ & $4.0 \pm 0.2^{\mathrm{d}}$ & $4.60 \pm 0.17^{\mathrm{d}}$ & $3.5 \pm 0.18^{\mathrm{e}}$ \\
\hline & 21 & $2.90 \pm 0.12^{\mathrm{e}}$ & $3.0 \pm 0.16^{\mathrm{e}}$ & $3.6 \pm 0.2^{\mathrm{e}}$ & $3.20 \pm 0.16^{\mathrm{e}}$ & $3.0 \pm 0.27^{\mathrm{e}}$ \\
\hline \multirow{4}{*}{$\begin{array}{l}\text { Beet root } \\
\text { cake } 5 \%\end{array}$} & 0 & $8.40 \pm 0.29^{b}$ & $8.5 \pm 0.39^{b}$ & $8.4 \pm 0.17^{\mathrm{a}}$ & $8.60 \pm 0.39^{\mathrm{a}}$ & $8.5 \pm 0.12^{a}$ \\
\hline & 7 & $8.00 \pm 0.23^{b}$ & $8.1 \pm 0.16^{b}$ & $7.9 \pm 0.25^{b}$ & $8.00 \pm 0.21^{\mathrm{a}}$ & $8.2 \pm 0.16^{\mathrm{a}}$ \\
\hline & 14 & $7.10 \pm 0.17^{\mathrm{c}}$ & $7.8 \pm 0.25^{\mathrm{c}}$ & $7.4 \pm 0.25$ b & $7.20 \pm 0.11^{b}$ & $7.3 \pm 0.24^{b}$ \\
\hline & 21 & $7.00 \pm 0.12^{\mathrm{c}}$ & $7.2 \pm 0.11^{\mathrm{c}}$ & $7.3 \pm 0.27^{b}$ & $7.00 \pm 0.14^{b}$ & $7.1 \pm 0.26^{b}$ \\
\hline \multirow{4}{*}{$\begin{array}{c}\text { Sweet } \\
\text { potato cake } \\
10 \%\end{array}$} & 0 & $8.30 \pm 0.22^{b}$ & $7.7 \pm 0.15^{\mathrm{c}}$ & $8.5 \pm 0.2^{\mathrm{a}}$ & $8.2 \pm 0.27^{\mathrm{a}}$ & $8.5 \pm 0.37^{a}$ \\
\hline & 7 & $7.00 \pm 0.17^{\mathrm{c}}$ & $6.7 \pm 0.23^{\mathrm{d}}$ & $6.6 \pm 0.13^{c}$ & $7.3 \pm 0.27^{b}$ & $7.5 \pm 0.23^{b}$ \\
\hline & 14 & $5.40 \pm 0.21^{\mathrm{d}}$ & $4.3 \pm 0.19^{\mathrm{e}}$ & $5.1 \pm 0.11^{\mathrm{c}}$ & $6.1 \pm 0.28^{c}$ & $5.2 \pm 0.22^{\mathrm{c}}$ \\
\hline & 21 & $2.80 \pm 0.16^{\mathrm{e}}$ & $2.5 \pm 0.11^{\mathrm{e}}$ & $3.7 \pm 0.13^{\mathrm{e}}$ & $4.5 \pm 0.15^{\mathrm{d}}$ & $3.2 \pm 0.13^{\mathrm{e}}$ \\
\hline \multirow{4}{*}{$\begin{array}{l}\text { Beet root } \\
\text { cake } 10 \%\end{array}$} & 0 & $8.00 \pm 0.37^{b}$ & $6.6 \pm 0.27^{\mathrm{d}}$ & $7.9 \pm 0.35^{b}$ & $8.2 \pm 0.32^{a}$ & $7.0 \pm 0.1^{\mathrm{b}}$ \\
\hline & 7 & $7.10 \pm 0.14^{\mathrm{c}}$ & $6.9 \pm 0.33^{\mathrm{d}}$ & $7.6 \pm 0.28^{b}$ & $6.8 \pm 0.21^{\mathrm{c}}$ & $6.7 \pm 0.14^{\mathrm{c}}$ \\
\hline & 14 & $6.70 \pm 0.18^{d}$ & $6.8 \pm 0.18^{\mathrm{d}}$ & $7.0 \pm 0.23^{b}$ & $6.5 \pm 0.24^{c}$ & $6.2 \pm 0.21^{\mathrm{c}}$ \\
\hline & 21 & $6.50 \pm 0.24^{\mathrm{d}}$ & $6.5 \pm 0.22^{\mathrm{d}}$ & $7.1 \pm 0.11^{\mathrm{b}}$ & $6.4 \pm 0.15^{c}$ & $5.8 \pm 0.22^{\mathrm{c}}$ \\
\hline \multirow{4}{*}{$\begin{array}{c}\text { Sweet } \\
\text { potato cake } \\
15 \%\end{array}$} & 0 & $8.00 \pm 0.29^{b}$ & $7.3 \pm 0.27^{\mathrm{c}}$ & $7.9 \pm 0.16^{b}$ & $7.9 \pm 0.32^{b}$ & $8.0 \pm 0.34^{\mathrm{a}}$ \\
\hline & 7 & $7.70 \pm 0.34^{\mathrm{c}}$ & $7.3 \pm 0.17^{\mathrm{c}}$ & $7.6 \pm 0.25^{b}$ & $7.8 \pm 0.26^{b}$ & $7.5 \pm 0.35^{b}$ \\
\hline & 14 & $7.70 \pm 0.18^{c}$ & $7.0 \pm 0.14^{\mathrm{c}}$ & $7.1 \pm 0.26^{b}$ & $7.4 \pm 0.22^{b}$ & $7.2 \pm 0.24^{b}$ \\
\hline & 21 & $7.10 \pm 0.21^{\mathrm{c}}$ & $6.7 \pm 0.2^{\mathrm{d}}$ & $6.5 \pm 0.29^{c}$ & $6.3 \pm 0.12^{c}$ & $7.0 \pm 0.18^{b}$ \\
\hline \multirow{4}{*}{$\begin{array}{l}\text { Beet root } \\
\text { cake } 15 \%\end{array}$} & 0 & $8.10 \pm 0.37^{b}$ & $9.0 \pm 0.39^{\mathrm{a}}$ & $7.0 \pm 0.33^{b}$ & $8.0 \pm 0.21^{\mathrm{a}}$ & $8.4 \pm 0.3^{a}$ \\
\hline & 7 & $7.5 \pm 0.25^{\mathrm{c}}$ & $7.5 \pm 0.2^{c}$ & $7.0 \pm 0.23^{b}$ & $8.0 \pm 0.29^{\mathrm{a}}$ & $7 \pm 0.31^{b}$ \\
\hline & 14 & $7.3 \pm 0.29^{c}$ & $6.5 \pm 0.21^{\mathrm{d}}$ & $7.0 \pm 0.28^{b}$ & $7.1 \pm 0.31^{b}$ & $6.8 \pm 0.21^{\mathrm{c}}$ \\
\hline & 21 & $6.00 \pm 0.21^{\mathrm{d}}$ & $5.2 \pm 0.11^{\mathrm{d}}$ & $6.4 \pm 0.15^{\mathrm{c}}$ & $6.3 \pm 0.19^{c}$ & $6.0 \pm 0.19^{\mathrm{c}}$ \\
\hline
\end{tabular}

All results are expressed as mean \pm SD

Values with the same letters indicate insignificant difference and vice versa. 
Rheological properties of sweet potato and beetroot cake is illustrated in Table (7) and Fig (2.3). The Farinograph measures and records resistance of dough to mixing. It is used to determine the stability and other characteristics of dough during mixing. Water absorption (\%) values gradually increased by addition levels $(5,10$, and $15 \%)$ of sweet potato and beetroot. The highest increase noticed in $15 \%$ sweet potato and beetroot cake. Water absorption of dough is the water to flour ratio that corresponds to the 500 Brabender units (BU) line in the Farinograph Rosell et al., (2010) reported that the differences in water absorption are mainly caused by the greater number of hydroxyl groups which exist in the fiber structure and allow more water interactions through hydrogen. This is generally lower than the baking or operational absorption Stauffer, (1998). Arrival time was the highest in beet root cake (15\%) comparing with control and sweet potato cake. Stability is the time difference between the point where the top of the curve first intersects the 500 $\mathrm{BU}$ line and the point where the top of curve leaves the
$500 \mathrm{BU}$ line. This gives a measure of tolerance of flour to mixing and the cohesiveness and elasticity of the dough Appolonia and Kunerth, (1994) the highest value was 10.5 min noticed in beet root cake $(15 \%)$. Rate of resilience ranged 100 to 60 in beet root cake $(15 \%)$ and control cake. Degree of weakening ranged from 120 to 50 (B.U) Brabender units in $5 \%$ beetroot cake and $15 \%$ sweet potato cake. flexibility after $5 \mathrm{~cm}$ (B.U) was the highest in control cake 145(B.U) Brabender units and the lowest value noticed in $15 \%$ beetroot cake 50 (B.U). Extensibility (mm) was the highest in $15 \%$ sweet potato cake $(1040 \mathrm{~mm})$. Proportional number (P.N.) was the highest in $15 \%$ beetroot cake 10.05 and the lowest in control cake 2.05 . The area below the curve $\mathrm{cm}_{2}$ was the highest in $5 \%$ beetroot cake (102). The addition of sweet potato powder significantly changed the rheological properties of wheat dough (water absorption and mixing tolerance index were increased, dough stability was reduced, and dough development time was prolonged Lauková et al., (2019)

Table 7. Effect of adding different levels of sweet potato and beetroot flour on Farinograph and Extensograph properties of prepared cake

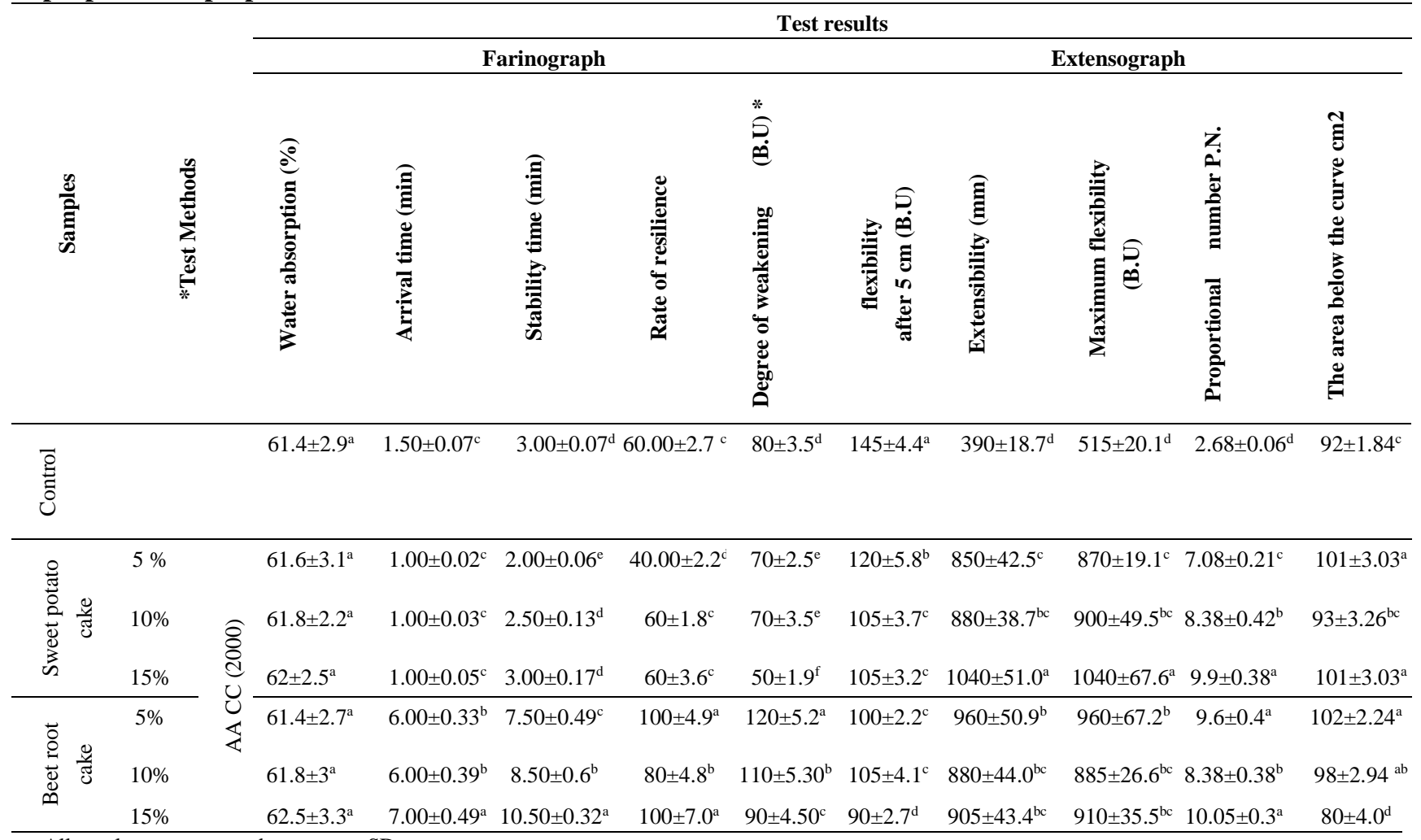

All results are expressed as mean \pm SD

Values with the same letters indicate insignificant difference and vice versa. 


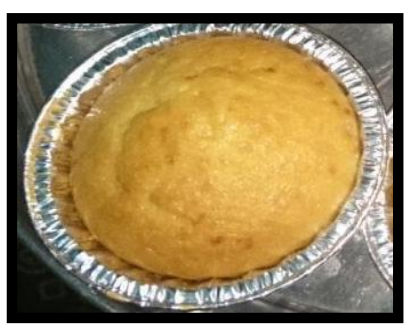

\section{Control cake}
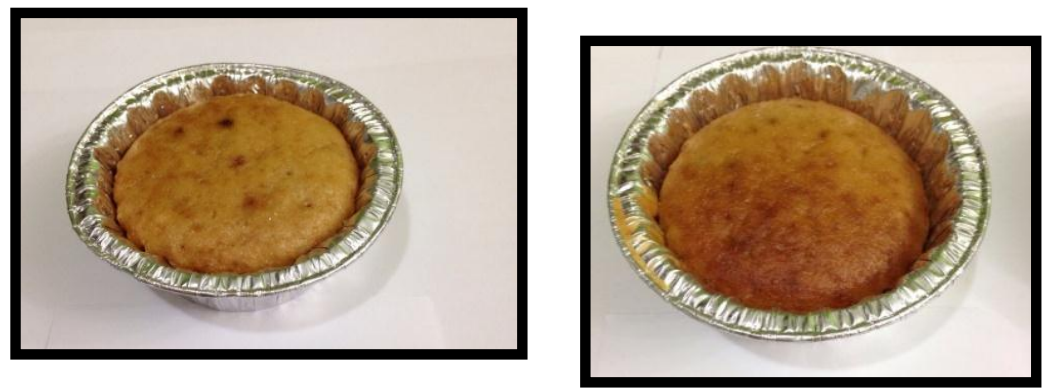

Sweet potato $5 \%$ cake

Sweet potato $10 \%$ cake

Sweet potato $15 \%$ cake
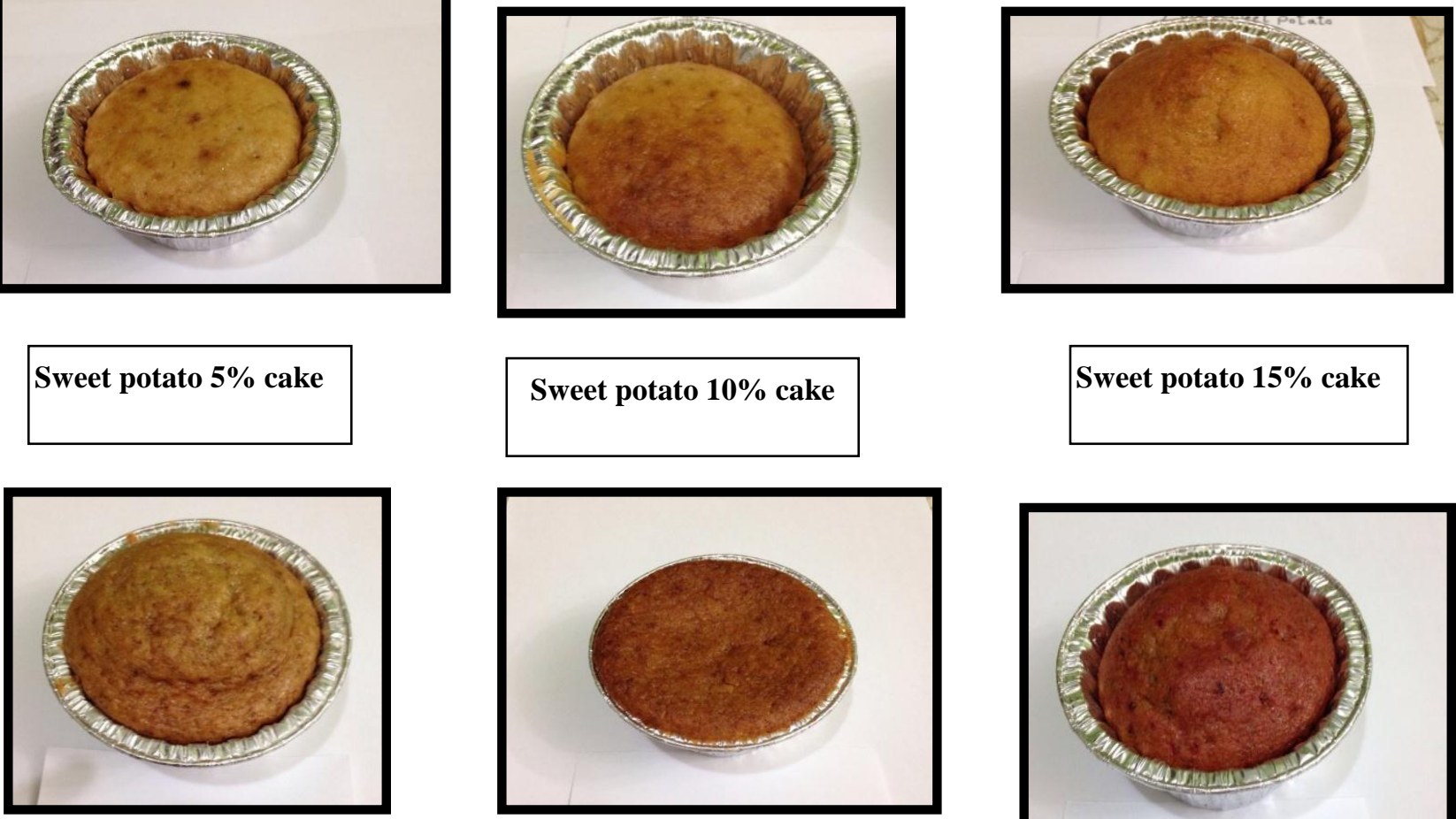

Beet root cake 5\%

Beet root cake $10 \%$

Beet root cake $15 \%$

Fig. 1. Photographs of cake fortified with different levels of sweet potato and beetroot 




\section{Control}
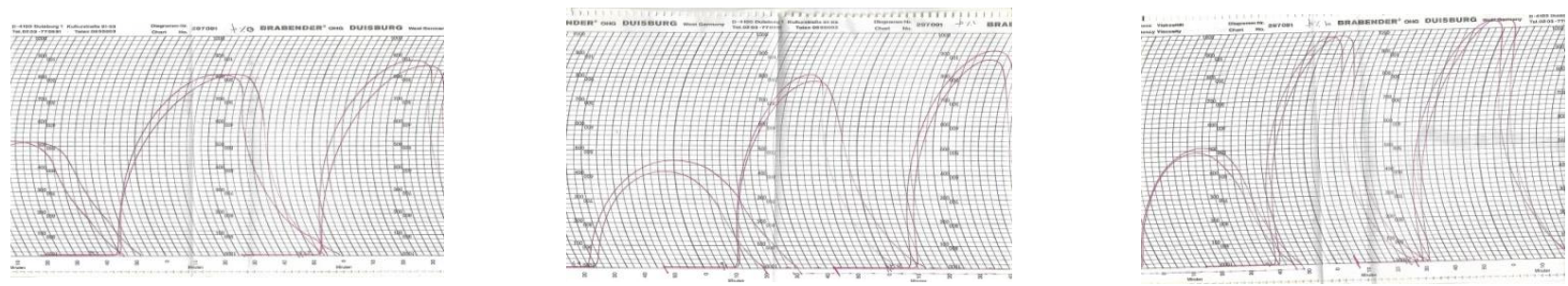

Sweet Potato 5\%

Sweet Potato $10 \%$
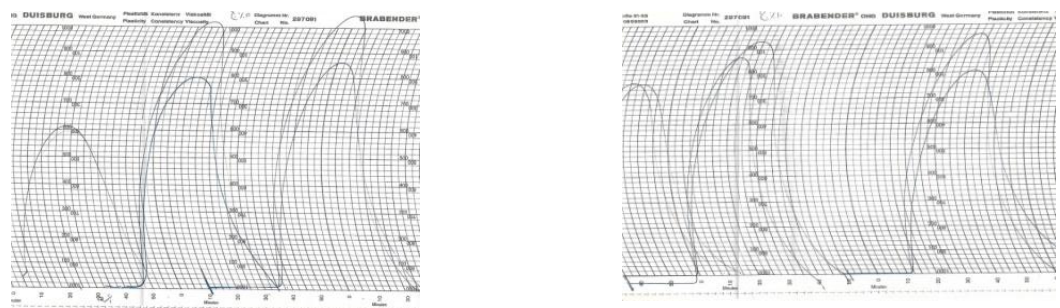

Sweet Potato $15 \%$

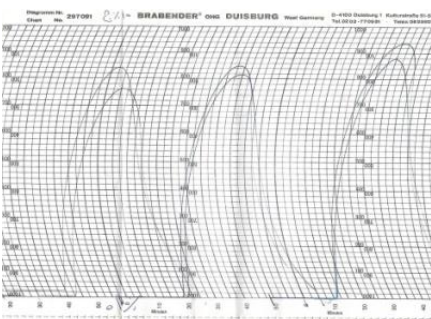

Beetroot $5 \%$

Beetroot $10 \%$

Beetroot $15 \%$

Fig. 2. Extensograph of cake fortified with different levels of sweet potato and beetroot 

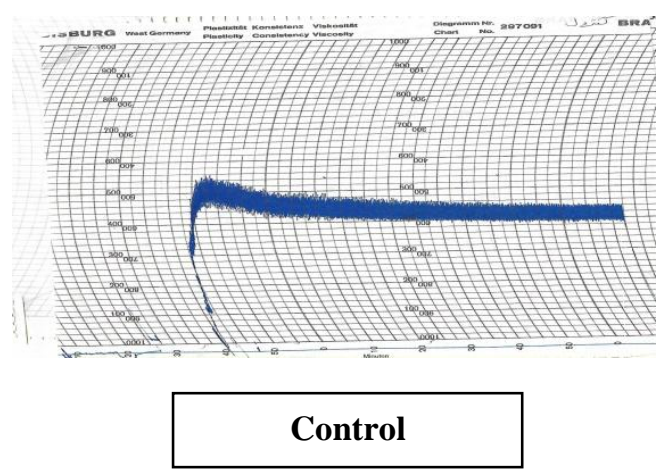

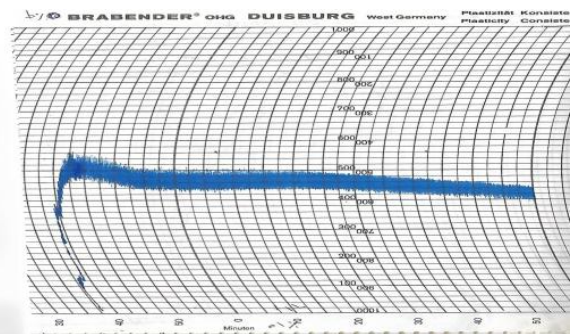

Sweet Potato $5 \%$

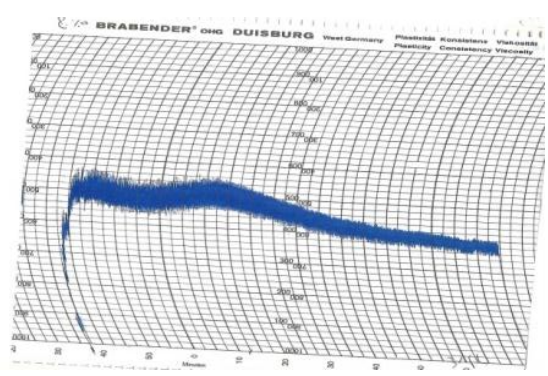

Beetroot 5\%

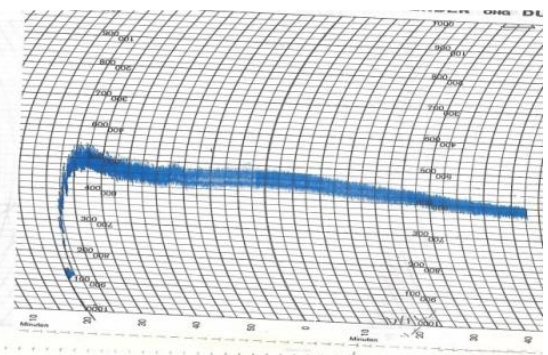

Sweet Potato $10 \%$

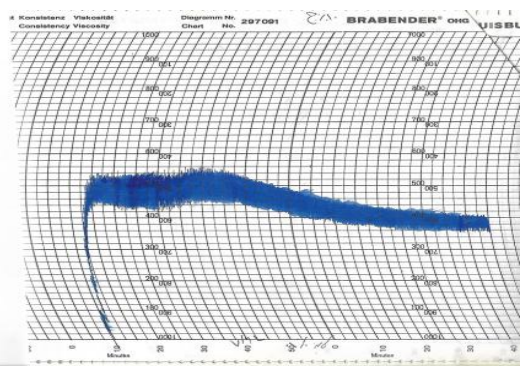

Beetroot $10 \%$

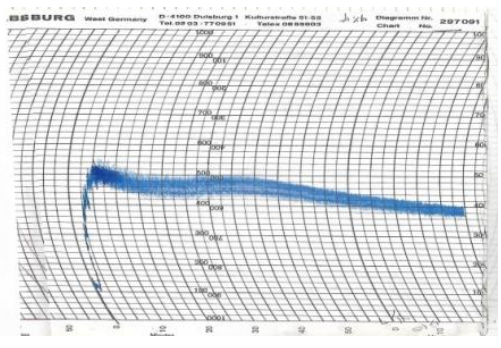

Sweet Potato $15 \%$

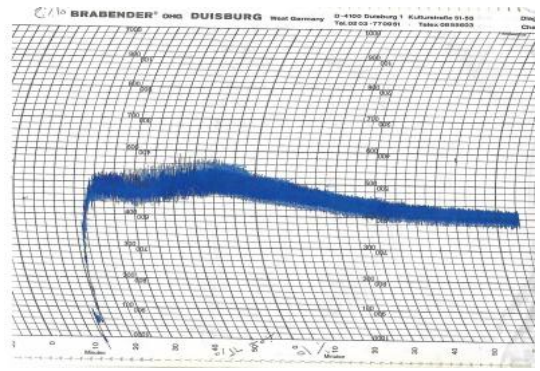

Beetroot 15\%

Fig. 3. Farinoghraph of cake fortified with different levels of sweet potato and beetroot 


\section{CONCLUSION}

It was found that sweet potato and beetroot contains a limited amount of protein, although rich in dietary fiber content and carbohydrate, so a successful combination with wheat flour for cake production would be nutritionally advantageous. Sweet potato and beetroot flour with wheat flour had significant effect on the functional properties of the flour blends. The results obtained could be very valuable in decision making for industries that want to take nutritional advantage of sweet potato and beetroot flour as alternative or supplement to cereal flours. Sweet potato and beetroot flour could be useful in the manufacture of highly nutritious cakes.

\section{REFERENCES}

A.A.C.C. 1983. American Association of cereal chemists, Approved methods of

AACC. 1984. Approved Methods, St. Paul, MN: American Association of Cereal Chemists.

Abd El-Wahab, G. I. A. 2016. Utilization of Sweet Potato Flour as Natural Antioxidant to Keeping Quality of Butter Cake during Storage. Sci. 6 (04):1066-1075.

Abo-Allam, R. M. 2003. Data Statistical Analysis Using SPSS Program. 1st ed., Publication for Universities, Cairo

Alshehry, G. A. 2019. Utilization of Beetroot As A Natural Antioxidant, Pigment and Antimicrobial in Cupcake During the Storage Period. International J. of Engineering Research \& Technology (IJERT) 8 (10).

AOAC. 2000. Official Methods of Analysis. 17th Edition, The Association of Official Analytical Chemists, Gaithersburg, MD, USA. Methods 925.10, 65.17, 974.24, 992.16.

Appolonia, B. L. D. and W. H. Kunerth. 1994. The Farinograph Handbook (3rd edition), American Association of Cereal Chemists, St Paul, USA.

Atef, A.M.A., T.R. Mostafa and A.A. Samia. 2011. Utilization of faba bean and cowpea flours in gluten free cake production. Australian J. of Basic and Applied Sci. 5(12): 2665-2672.

Awasthi, P. 2014. Sensory and nutritional evaluation of value added cakes formulated by incorporating beetroot powder. International j. of food and nutritional sci. 3(6):145-148.

Bhat, M.A. and A.Bhat. 2013. Study on Physico-Chemical Characteristics of Pumpkin Blended Cake. J. of Food Processing and Technology. 4(9): 4-9.

Burri, B. J. 2011. "Evaluating sweet potato as an intervention food to prevent vitamin A deficiency." Comprehensive Reviews in Food Sci. and Food Safety. 10(2): 118-130.

Čanadanović-Brunet, J. M., S. S.Savatović, G. S. Ćetković, J. J. Vulić, S. M.Djilas, S. L.Markov and D. D. Cvetković. 2011. Antioxidant and antimicrobial activities of beet root pomace extracts. Czech Journal of Food Sci. 29 (6): 575-585
Dias, M.G., M.F.G.F.C. Camoes, L. Oliveira. 2009. "Carotenoids in traditional Portuguese fruits and vegetables". Food Chemistry. 113:808-815.

Frank, T., F.C. Stintzing, R. Carle, I. Bitsch, D. Quaas, G. Strass and M. Netzel. 2005. Urinary pharmacokinetics of betalains following consumption of red beet juice in healthy humans. Pharmacol. Res. 52:290-297.

Georgiev, V.G., J. Weber, E.M. Kneschke, P.N. Denev, T. Bley and A.I. Pavlov. 2010. Antioxidant activity and phenolic content of betalain extracts from intact plants and hairy root cultures of the red beetroot Beta vulgaris cv. Detroit dark red. Plant Foods Hum. Nutr. 65:105-111.

Hafez, A. A. 2012. Physico-chemical and sensory properties of cakes supplemented with different concentration of marjoram. Australian J. of Basic and Applied Sci. 6(13): 463-470.

Ihekoronye, A. I. and P. O. Ngoddy. 1985. Integrated food sci. and technology for the tropics. Macmillan.

Jastrebova, J., C. Witthoft, A. Grahn, U. Svensson, M. Jagerstad. 2003. "HPLC Determination of folates in raw and processed beetroots," Food Chemistry80 .579-588

Kirk, S. and R. Sawyer. 1991. Pearson's composition and analysis of foods (No. Ed. 9). Longman Group Ltd.

Lauková, M., L. Minarovičová, J. Karovičová and Z. Kohajdová 2019. Quality evaluation of sweet potato powder-enriched cereal products. Food Sci. and Technology International .

Lundberg, J.O., E. Weitzberg, M.T. Gladwin. 2008. The nitrate-nitrite-nitric oxide pathway in physiology and therapeutics. Nature Reviews Drug Discovery. 7:156167.

Manach, C., G. Williamson, C. Morand, A. Scalbert and C. Rémésy. 2005. Bioavailability and bioefficacy of polyphenols in humans. I. Review of 97 bioavailability studies. Am. J. Clin. Nutr. 81:230-242.

Meda, A., C. E. Lamien, M. Romito, J. Millogo and O. G. Nacoulma. 2005. Determination of the total phenolic, flavonoid and proline contents in Burkina Fasan honey, as well as their radical scavenging activity, Food Chemistry. 91 (3): 571-577.

Nazni, P. and T. D. Karuna. 2011. Optimization of beetroot peel osmotic dehydration process using response Surface methodology, International Journal of Current Research. 3(8):027-032.

Ohizua, E. R., A. A. Adeola, M. A. Idowu, O. P. Sobukola, T. A. Afolabi, R. O. Ishola and A. Falomo. 2017. Nutrient composition, functional, and pasting properties of unripe cooking banana, pigeon pea, and sweetpotato flour blends. Food sci. \& nutrition. 5(3):750-762.

Okorie, S.U. and E.N. Onyeneke. 2012. Production and Quality evaluation of backed cake from blend of sweet potatoes and Wheat flour -Part-I: Natural \& Applied Sci. 3(2):9944-9953

Olatunde, S. J., O. M. Ajayi, G. O.Ogunlakin and A. S. Ajala. 2019. Nutritional and sensory properties of cake made from blends of pigeon pea, sweet potato and wheat flours. Food Research. 3 (5): 456-462. 
Rodríguez, R., A. Jimenez, J. Fernández-Bolaños, R. Guillén and A. Heredia. 2006 . Dietary Fiber from Vegetable Products as Source of Functional Ingredients. Trends in Food Sci. and Technology. 17:3-15.

Rosell, C. M., C. Marco, J. García-Alvárez and J. Salazar. 2010. Rheological properties of rice-soybean protein composite flours assessed by Mixolab and ultrasound. $J$. Food Process Eng. DOI: 10.1111/j.17454530.2009.00501.x.

Singh, S., C.S. Riar and D.C. Saxena. 2008. "Effect of incorporating sweet potato flour to wheat flour on the quality characteristics of cookies." African j. of food sci. 2:065072
Stauffer, C.E. 1998. Principles of dough formation. pp. 262295. In: Cauvain, C.P. and Young, L.S. (Ed.). Technology of Bread Making, Campden and Chorleywood Food Res. Asso., Gloucestershire, U.K.

Tarladgis, B. G., B.B. Watts, N.T. Younathan and L. Dugan. 1960. A distillation method for the quantitative determination of malonaldehyde in rancid foods. J. Am. Oil. Chem. Soc. 37:44.

Vali, L., E. Stefanovits-Banyai, K. Szentmihalyi, H. Febel, E.Sardi, A.Lugasi, I.Kocsis, A. Blazovics. 2007. "Liverprotecting effects of table beet (Beta vulgaris var.Rubra) during ischemia-reperfusion,"sNutrition. 23: 172-178.

van Velzen, A.G., A.J. Sips, R.C. Schothorst, A.C. Lambers, J. Meulenbelt. 2008. The oral bioavailabilityof nitrate from nitrate-rich vegetables in humans. Toxicology Letters. 181:177-181. DOI:10.1016/j.toxlet..07.019

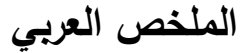

\section{تدعيم الكيك بدقيق البطاطا الحلوة والبنجر كمضاد طبيعي للأكسدة أثناء التخزين}

$$
\text { رشا محمد نجيب ، نهله صلاح زيدان }
$$

أظهرت نتائج التقييم الحسي للكيك انخفاض في الخواص الحسية بزيادة فترة التخزين مقارنة مع الكيك الكنترول كذلك تم تقدير الخواص الريولوجية للعجين كما تم تقديرالمواد المضادة للأكسدة وأظهرت النتائج ان البطاطا الحلوة والبنجر مصدرا جيدًا للفينولات، ومركبات الفلافونويدات لذلك توصى الدراسة بإضافة كل من البطاطا الحلوة والبنجر للكيك لتأثيرهم الإيجابى على القيمة الغذائية والوظيفية وكذللك الخصائص الحسية خلال فترة التخزين للكيك.

الكلمات الدالة: البطاطا الحلوة، البنجر، مضادات

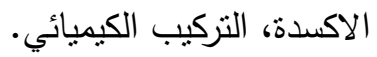

تعد البطاطا الحلوة والبنجر من الأغذية ذات القيمة الغذائية العالية، ليس فقط لما تحتويه من السكريات والمعادن ولكن لما تحتويه أيضا من الفيتامينات والبيتا كاروتين الذى يعتبرمصدر من المصادر الرخيصة لفيتامين أ. في هذه الدراسة تم تقييم جودة الكيلك المعد بنسب مختلفة من البطاطا الحلوة والبنجر وهي 0، • 1، 10 \% مع دقيق القمح، وتم تخزين هذه المنتجات لمدة V،؛ (، آبيومًا. وقد أظهرت النتائج أن هناك زيادة في محتوى المواد الغذائية (البروتين، الرماد، الألباف، الفينولات والفلافونويدات) عند تدعيم دقيق القمح بالبطاطا الحلوة والبنجر. علاوة على زيادة محتوى

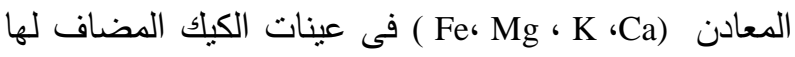
البطاطا الحلوة والبنجر مقارنة مع الكيك الكنترول فى حين 